\title{
Cryosols from Tundra and Taiga Zones of Yakutia: Properties, Clay Mineralogy, and Problems of Classification
}

\author{
R. V. Desyatkin ${ }^{a, *}$, S. N. Lessovaia ${ }^{b}$, M. V. Okoneshnikova ${ }^{a}$, and A. Z. Ivanova ${ }^{a}$ \\ ${ }^{a}$ Institute of Biological Problems of the Cryolithozone, Siberian Branch, Russian Academy of Sciences, Yakutsk, 667891 Russia \\ ${ }^{b}$ Institute of Earth Sciences, St. Petersburg State University, St. Petersburg, 199178 Russia \\ *e-mail:rvdes@ibpc.ysn.ru
}

Received April 20, 2021; revised June 16, 2021; accepted June 30, 2021

\begin{abstract}
Data on major properties and clay mineralogy in the profiles of slightly differentiated Cryosols forming in cold ultracontinental climate of Yakutia are discussed. The particular objects are represented by the cryozems of tundra, forest-tundra, and northern taiga of the Anabar and Alazeya plateaus and by the palevaya (pale) soil of middle taiga in Central Yakutia. The differentiation of clay minerals in the vertical soil profiles is poorly pronounced because of the strong homogenizing impact of cryoturbation processes. The profile of pale soil displays minor differences in clay mineralogy despite the strong difference in acid-base conditions of the upper and lower horizons. However, the obtained data suggest that mineral weathering in pale soils of Central Yakutia is more advanced than it was concluded in the 1970s on the basis of data on the absence of pronounced trends in the vertical distribution of clay minerals in their profiles. This is in good agreement with the presence of a sufficiently thick upper humus horizon in these soils, which is typical of the soils of more humid regions. It is suggested that pale soils of Central Yakutia should be classified as soddy pale soils.
\end{abstract}

Keywords: permafrost affected soils, clay minerals, soil classification

DOI: $10.1134 / \mathrm{S} 1064229321120048$

\section{INTRODUCTION}

Soil formation and weathering in the vast permafrost zone of northeastern Siberia and, particularly, the Sakha (Yakutia) Republic proceed under conditions close to extreme. This is one of the coldest places in Eurasia with an ultracontinental climate characterized by a very long period (6.5-9 months) with subzero temperatures and sharp annual temperature fluctuations reaching $70-100^{\circ} \mathrm{C}$. The mean annual precipitation is lower than the potential evaporation [17]. The territory of Yakutia encompasses several natural zones. Evaporation in forest ecosystems is higher than that in tundra ecosystems [34], and permafrost is a significant source of moisture to ensure forest growth [1, $9,43]$. The cold, ultracontinental climate of Yakutia differs from the climatic conditions of cold, but more humid regions, where soils with permafrost are also widespread [6, 36].

The foundations of the study of soils in Yakutia were laid in the works of the classics of Russian soil science [4, 9-11, 22, 23]. Physical and chemical properties of soils, their genesis, and classification issues were thoroughly considered. Much less is known about the mineralogical composition of Yakutian soils. For such a vast region, the chemical and mineralogical properties were studied in the soils of the Kolyma Lowland [27, 31] and the Central Yakutian
Plain [24], including the results of our studies [8, 38]. Currently, data on the mineralogical composition of rocks and soils and on the distribution of clay minerals in the soil profile are particularly important. The clay fraction of soils is a sensitive indicator of the direction of pedogenesis. Under conditions of global climate change, it is necessary to have more detailed data on the soils of insufficiently studied and difficultly accessible regions. In particular, these are the areas with the ice complex deposits, where intense degradation of ground ice and associated disturbances in the soil cover take place; serious disturbances are also observed in the water balance and hydrological regime of rivers. Deep soil thawing leads to the involvement of new material into the thawed layer; as a consequence, the morphogenetic characteristics of the soils change. In addition, the development of the new classification system of Russian soils [12, 20] raised the question of adequate placement of many soils of Yakutia into this system.

The aim of this work is to study the macromorphological, physicochemical, and chemical properties and mineralogical composition of weakly differentiated soils forming in the cold ultracontinental climate in the tundra and taiga zones of Yakutia for a better understanding of their genesis and position in the new classification system. 


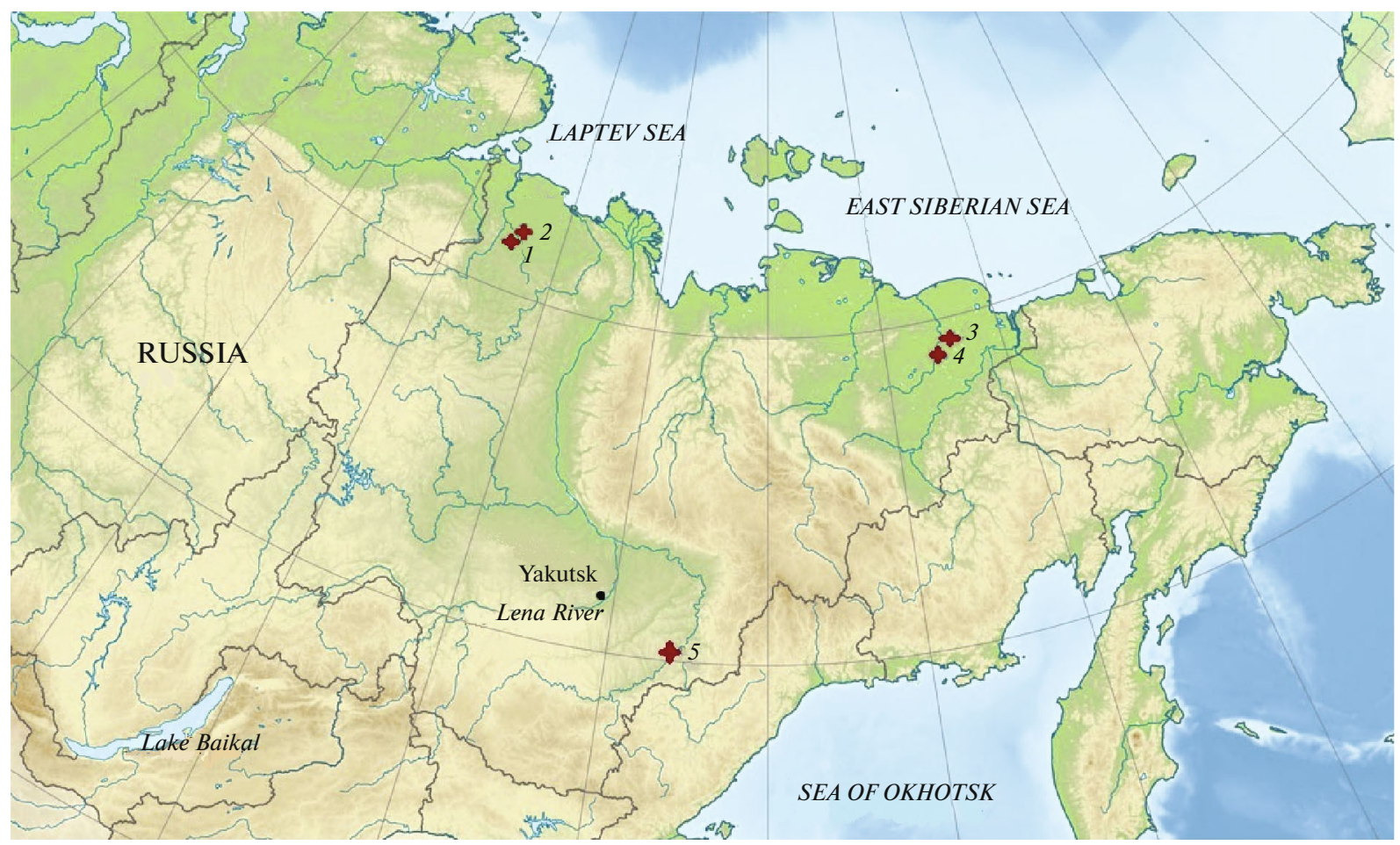

Fig. 1. Location of studied soil pits: (1) P-18.12.A, (2) P-12.12.A (the Anabar Plateau), (3) P-31.08.Al, (4) P-04.09.Al (the Alazeya Plateau), and (5) P-0-1-11 (the Central Yakutian Plain).

\section{OBJECTS OF STUDY}

Research objects are located in a wide geographic range within the permafrost zone. Three key areas, significantly distant from one another, include the Anabar Plateau, the Alazeya Plateau, and the Central Yakutian Plain (Fig. 1). Soil pits were studied in the tundra, forest-tundra, and taiga (northern and middle taiga subzones). The Anabar and Alazeya plateaus are found in remote and difficultly accessible areas and their soils remain insufficiently studied. In contrast, the key site within the Central Yakutian Plain is located at the Elgeeyi experimental station, which is part of the network of stations for international environmental monitoring. The classification position and properties of the soil studied at this station, except for the mineralogical composition, were considered earlier [18].

Soils of the Anabar Plateau. The Anabar Plateau is one of the oldest geological structures of the Precambrian age. It is located in northwestern Yakutia and is bordered by the mountains of the Putorana Plateau from the west and by the Lena River valley from the east. The metamorphic complex of Archean rocks is represented by various crystalline schists and gneisses with granite intrusions [16, 25]. On the periphery, the plateau is framed by Proterozoic and Lower Paleozoic limestones [19]. The study site is located in the northeast of the Siberian platform, on the eastern periphery of the Anabar Shield, and belongs to the Anabar River basin. Cambrian calcareous rocks of the plateau are dissected by tributaries of the river [5]. Permafrost has a thickness of 700-800 $\mathrm{m}$; its temperature in the upper layer ranges from -5 to $-10^{\circ} \mathrm{C}$. The depth of seasonal thawing does not exceed $0.8 \mathrm{~m}[14,15]$. The mean July air temperature is $+12^{\circ} \mathrm{C}$, and the mean January air temperature is $-35.1{ }^{\circ} \mathrm{C}$. The mean e annual precipitation is $130-230 \mathrm{~mm}$ [17].

Key areas were located in the zone of continuous permafrost in the tundra and larch woodland. Pit P-18.12.A $\left(71^{\circ} 16^{\prime} 46^{\prime \prime} \mathrm{N}, 114^{\circ} 28^{\prime} 38^{\prime \prime} \mathrm{E}\right)$ was laid in the dryadcotton grass-moss tundra, on a slightly wavy surface of the top of local levee on the left bank of the Mayat River. The soil profile had the following horizonation: $\mathrm{O}(0-7 \mathrm{~cm})$, moss and fresh litter; Oao $(7-12 \mathrm{~cm})$, rawhumus litter with undecomposed and weakly decomposed plant residues and roots; CRg $(12-31 \mathrm{~cm})$, cryogenic gleyic horizon of brownish gray color with ocherous mottles, sandy loamy, structureless, satiated wet; $\mathrm{Cg} \perp(31-50 \mathrm{~cm})$, gleyic silt loamy horizon of grayish color, satiated wet, underlain by the low-ice permafrost. The effervescence was absent in the entire profile. Parent rocks were represented by the sandy loamy derivatives of the Proterozoic and Cambrian rocks drained by the river and redeposited by it. The mineral horizons contained inclusions of gravel derived from the clayey calcareous bedrock. The diameter of the inclusions was up to $10 \mathrm{~cm}$ in the $\mathrm{CRg}$ horizon and up to $15 \mathrm{~cm}$ in the $\mathrm{Cg} \perp$ horizon. According to the Russian soil classification system [12, 20], this soil should be classified as a gleyic raw-humus 
cryozem. The traditionally used name for this soil in Yakutia [10] is permafrost-affected gley tundra soil. In accordance with international approaches [35], this is a Reductaquic Cryosol (Eutric, Loamic).

The second key area was found in a dwarf shrublichen-moss larch woodland with hummocky microtopography and clearly pronounced surface frost cracking. Pit R-12.12.A $\left(71^{\circ} 21^{\prime} 28^{\prime \prime} \mathrm{N}, 114^{\circ} 38^{\prime} 18^{\prime \prime} \mathrm{E}\right)$ was laid in the valley of brook 41, basin of the Mayat River, on the top of the levee on the first terrace. The parent material represented colluvial derivative of the ancient weathering mantle of the Anabar Plateau. The soil had the following horizonation: $\mathrm{O}(0-3 \mathrm{~cm})$, moss and lichen tissues; Oao $(3-8 \mathrm{~cm})$, raw-humus litter with mainly weakly decomposed plant remains; CRg $(8-34 \mathrm{~cm})$, light grayish brown, with bluish mottles, structureless, with signs of thixotropy, dense; $\mathrm{C} \perp(34-60 \mathrm{~cm})$, brownish gray, without gley features. The profile did not effervesce with $\mathrm{HCl}$. Permafrost with ice crystals was at a depth of $60 \mathrm{~cm}$. This soil was classified as a gleyic raw-humus cryozem [12, 20], or a typical cryozem [10], or an Oxyaquic Turbic Cryosol (Eutric, Loamic) [35].

Soils of the Alazeya Plateau. Key plots within the Alazeya Plateau (northeastern Yakutia) were studied along the Alazeya River. A larger part of the river basin is located in the northern taiga subzone (up to $69^{\circ} \mathrm{N}$ ); the tundra zone is between $69^{\circ}$ and $71^{\circ} \mathrm{N}$. The soilforming rocks are dark gray alluvial, lacustrine-alluvial, lacustrine-bog, colluvial-solifluction, and cryogenic eolian Quaternary sediments of up to dozens of meters in thickness. The seasonal thawing depth reaches $50-70 \mathrm{~cm}$. The mean July air temperature is $+13.4^{\circ} \mathrm{C}$, and the mean January air temperature is $-37.3^{\circ} \mathrm{C}$. The mean annual precipitation is $209-$ $275 \mathrm{~mm}$ (data for the Srednekolymsk weather station) [13-15].

Pit P-31.08.Al $\left(69^{\circ} 45^{\prime} 03^{\prime \prime} \mathrm{N}, 154^{\circ} 57^{\prime} 52^{\prime \prime}\right.$ E) was laid in the foothill area (Kisilyakh-Tas area) with a pronounced hummocky microtopography on the left bank of the Alazeya River under the grassy-dwarf shrub-green moss tundra. The relative height of the terrace-like surface was 3-4 m above the water level. The soil had the following horizons: Oao $(0-2 \mathrm{~cm})$, raw-humus litter with abundant strongly decomposed plant remains; CRcrm $(2-57 \mathrm{~cm})$, cryometamorphic horizon of light grayish brown color, moist, loamy sandy, with curdled-granular structure; CRg $\perp$ (57$65 \mathrm{~cm}$ ), a darker brownish gray horizon with ocherous mottles, coarse blocky structure. No effervescence was observed in the soil profile. The soil was frozen from the depth of $65 \mathrm{~cm}$. This soil profile was classified as a gleyic raw-humus cryometamorphized cryozem $[12,20]$, or a gleyic permafrost tundra soil [10], or a Cambic Turbic Cryosol (Eutric, Siltic) [35].

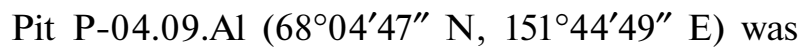
studied in a dwarf-lichen-green moss larch forest on the terrace of the left bank of the Alazeya River, not far from the village of Svatai. The hummocky microto- pography was clearly expressed. The soil profile consisted of the following horizons: living moss tissues $(0-10 \mathrm{~cm})$ with litter of shrubs; Oao $(10-12 \mathrm{~cm})$, reddish brown with a large number of roots, weakly decomposed/undecomposed plant remains; $\mathrm{CRg} \perp$ $(12-50 \mathrm{~cm})$ brownish gray with ocherous mottles, moist, poorly structured, dense, slightly thixotropic. The effervescence was absent in the profile. From the depth of $50 \mathrm{~cm}$, the soil was in the frozen state. This soil was classified as a gleyic raw-humus cryozem [12, 20] or a typical cryozem [10], or a Reductaquic Turbic Cryosol (Eutric, Loamic) [35].

Soil of the Central Yakutian Plain. The Central Yakutian Plain represents a set of Pleistocene terraces overlain by predominantly loesslike loams typical of the vast periglacial area of Siberia [21] and the periglacial hyperzone of Northern Eurasia [3]. The mineralogical composition of loesslike loam of the ice complex of Central Yakutia is practically uniform both in the spatial strike and in the vertical profile [41]. The mean July air temperature is $+18^{\circ} \mathrm{C}$, and the mean January air temperature is $-42.2^{\circ} \mathrm{C}$; the mean annual precipitation reaches $300 \mathrm{~mm}$ [17]. The thawing depth in the forest is about $1-1.5 \mathrm{~m}$; within open places, it increases up to $3 \mathrm{~m}[14,15]$.

Pit R-01-11 $\left(60^{\circ} 00^{\prime} 59^{\prime \prime} \mathrm{N}, 133^{\circ} 49^{\prime} 54^{\prime \prime}\right.$ E) was laid $60 \mathrm{~km}$ south of the village of Ust-Maya, in a lingonberry larch forest on the left bank of the Aldan River. The soil-forming rocks in the profile are represented by eluvial carbonate loams, which do not belong to loesslike deposits that are widespread in the Central Yakutian Plain. Permafrost was found at a depth of $88 \mathrm{~cm}$. The profile is characterized by the following sequence of horizons: $O(0-6(20) \mathrm{cm})$, litter horizon with mainly weakly decomposed plant remains and abundant roots; A (6(20) -11(24) cm), gray, loose, slightly dry humus horizon with very fine crumb structure; B (11(24) $-25(30) \mathrm{cm})$, light gray, fine crumb structure, slightly effervescent; this horizon disappears in the zones of cryogenic fissures; Bca $(25(30)-56 \mathrm{~cm})$, gray horizon with distinct effervescence; Cca $(56-88 \mathrm{~cm})$, yellowish pale brown, strongly effervescent. The underlying permafrost has a low ice content. The horizons of this profile are designated according to [10]. This soil was classified as a permafrost-affected palevaya (pale) soil, or as a Cambic Cryosol (Eutric, Loamic) [35]. In accordance with the approaches of the new Russian soil classification system [12,20], the classification name of this soil profile is debatable and will be discussed below.

Thus, the objects of research are represented by permafrost-affected tundra soils (cryozems) of the Anabar and Alazeya plateaus and by the permafrostaffected palevaya soil of the Central Yakutian Plain.

\section{METHODS}

The names of soils traditionally used in the Republic of Sakha [10] were given along with the names 
according to the new Russian soil classification system $[12,20]$ and the WRB system [35]. Symbols of soil horizons are given according to [12, 20], except for the palevaya soil, for which the horizons were designated in accordance with [10]. Particle-size distribution was determined by the pipette method according to Kachinskii (in modification by the V.V. Dokuchaev Soil Science Institute); the soil $\mathrm{pH}$ was determined by potentiometric method. The organic carbon content was determined by the Tyurin (wet combustion) method. In $r$ the upper horizons enriched with incompletely decomposed plant residues, the loss on ignition was determined. The analytical characterization of soils also included the determination of hygroscopic moisture, solid phase density, exchangeable cations and total (hydrolytic) acidity (according to Gedroits); in the palevaya soil (Cambic Cryosol) with the presence of carbonates, the exchangeable cations were determined by the Pfeffer method, and the $\mathrm{CO}_{2}$ of carbonates, by acidimetric method.

To determine the mineralogical composition, carbonates in effervescent fine earth samples were destroyed with $9 \%$ acetic acid. Clay $(<0.001 \mathrm{~mm})$ fraction was isolated by the Gorbunov method with the use of $1 \mathrm{M} \mathrm{MgCl}_{2}$ solution for clay coagulation. Sample pretreatment included ethylene glycol solvation and heating at $550^{\circ} \mathrm{C}$ for $3 \mathrm{~h}$. Oriented samples on glass slides were taken on a Rigaku MiniFlex II instrument (Rigaku Corporation, Tokyo, Japan) X-ray diffractometer (XRD), Co $K_{a}$. The diagnostics of clay minerals according to $\mathrm{X}$-ray diffraction patterns was carried out in accordance with [30,33].

\section{RESULTS}

Analytical characteristics. According to particlesize distribution data, the studied soils are silt loamy soils, except for one loamy sandy soil (pit P-31.08.Al) from the Alazeya Plateau (Table 1). Coarse silt fraction predominates in the shallow soils of the Anabar and Alazeya plateaus. In the palevaya soil from the Central Yakutian Plain (P-01-11), two maxima-fine sand and coarse silt-are expressed on particle-size distribution curves. There are no distinct regularities in the vertical redistribution of particle-size fractions in the soil profiles.

High values of the losses on ignition in the upper organic (O) horizons of studied are common for such horizons with a high content of weakly decomposed plant residues (Table 2). The humus-accumulative horizon A was formed only in the southernmost of the studied profiles in the middle taiga of Central Yakutia (P-01-11, palevaya soil). The horizon is characterized by a high content of organic carbon with a sharp decrease down the profile (Table 3 ). In the northern soils (the Anabar and Alazeya plateaus), neutral and slightly alkaline reaction in the upper horizons (with a minimum $\mathrm{pH}$ in the $\mathrm{O}$ horizon) is only observed in profile P-18.12.A, though this soil does not effervesce with $\mathrm{HCl}$ (Table 2). In other soils, acid reaction in the $\mathrm{O}$ horizons is replaced by slightly acid or neutral reaction in the mineral horizons. These values of $\mathrm{pH}$ are in agreement with low values of the total (hydrolytic) acidity and exchangeable hydrogen in the mineral horizons. In contrast to the mineral horizons, the high content of organic matter in the $\mathrm{O}$ horizons leads to an increased total acidity and lower base saturation. Calcium predominates among the exchangeable cations with a pronounced biogenic accumulation of this element in the horizons with the high content of organic matter. In the palevaya soil (P-01-11) of Central Yakutia, vertical differentiation of $\mathrm{pH}$ values is clearly pronounced: the soil reaction is acid in the $\mathrm{O}$ and $\mathrm{A}$ horizon, neutral in the B horizon, and alkaline in the Bca and Cca horizons (Table 3). The total acidity is increased in the upper horizons with relatively low $\mathrm{pH}$ values and sharply decreasing down the soil profile. The humus horizon is unsaturated with bases, as opposed to the $\mathrm{B}$ horizon. Calcium predominates among the exchangeable cations; its relative content increases from the A horizon downward through the soil profile. Earlier, it was shown that the biogenic accumulation of $\mathrm{Ca}$ in the upper part of palevye (pale) soils of Central Yakutia is not pronounced [8]. The exchangeable sodium content is low; according to this indicator, the soil cannot be attributed to solodized pale soils.

Mineralogical composition of the clay fraction. The following individual minerals were identified: dioctahedral mica / illite, chlorite, and kaolinite. The presence of kaolinite in the presence of chlorite in the sample is indicated by the splitting of the peak to $3.54 \AA-$ $d_{004}$ (chlorite) and $3.58 \AA-d_{002}$ (kaolinite). The smectitic structures were identified by a reflection at $\geq 17 \AA$ in the XRD patterns of solvated samples and by the absence of a reflection at $002 \sim 8.49 \AA$, which is characteristic of pure smectite. The latter indicates that the smectitic structures are represented by irregular mixed-layer mica-smectitic formations with a high content $(\geq 50 \%)$ of smectite layers. The presence of irregular chlorite-vermiculite (smectitic) structures in the sample is indicated by the appearance of a reflection in the range of 10-14 $\AA$ in the XRD patterns of the heated samples. Quartz, feldspars, and calcite were identified in the clay fraction as non-clay minerals.

In the soils of the Anabar Plateau, a single association of minerals inherited from the parent rock was identified: smectitic structures (irregular mixed-layer mica-smectite), illite, chlorite, kaolinite, and nonclay minerals (quartz and feldspars). The $\mathrm{Cg} \perp$ horizon in pit P-18.12.A was specified by a higher content of smectitic structures as judged from the ratio of the intensities of reflections at 17 and $14 \AA$ in the XRD patterns of solvated samples (Fig. 2). In contrast to the soils of the Anabar Plateau, irregular chlorite-vermiculite structures were identified, whereas the smectitic structures were absent. Accordingly, illite, kaolinite, 
Table 1. Particle-size distribution and solid phase density of the studied soils

\begin{tabular}{|c|c|c|c|c|c|c|c|c|c|}
\hline \multirow{2}{*}{$\begin{array}{l}\text { Horizon; depth, } \\
\mathrm{cm}\end{array}$} & \multicolumn{7}{|c|}{ Particle size, mm; particle content, $\%$} & \multirow{2}{*}{$\mathrm{HM}, \%$} & \multirow{2}{*}{$\begin{array}{c}\text { Solid phase } \\
\text { density, } \mathrm{g} / \mathrm{cm}^{3}\end{array}$} \\
\hline & $1.0-0.25$ & $0.25-0.05$ & $0.05-0.01$ & $0.01-0.005$ & $0.005-0.001$ & $<0.001$ & $<0.01$ & & \\
\hline \multicolumn{10}{|c|}{ Anabar Plateau } \\
\hline \multicolumn{10}{|c|}{ Pit P-18.12.A, gleyic raw-humus cryozem (tundra) } \\
\hline CRg, 12-31 & 1.8 & 23.8 & 44.5 & 6.6 & 7.7 & 15.6 & 29.9 & 1.86 & 2.59 \\
\hline $\mathrm{Cg} \perp, 31-50$ & 0.7 & 18.8 & 45.7 & 6.6 & 8.9 & 19.3 & 34.8 & 1.76 & 2.64 \\
\hline \multicolumn{10}{|c|}{ Pit P-12.12.A, gleyic raw-humus cryozem (larch woodland) } \\
\hline $\mathrm{CRg}, 8-34$ & 1.0 & 19.7 & 40.0 & 7.8 & 12.2 & 19.3 & 39.3 & 2.39 & 2.61 \\
\hline $\mathrm{C} \perp, 34-60$ & 1.4 & 18.1 & 42.9 & 7.3 & 11.9 & 18.4 & 37.6 & 2.09 & 2.60 \\
\hline \multicolumn{10}{|c|}{ Alazeya Plateau } \\
\hline \multicolumn{10}{|c|}{ Pit P-31.08.Al, gleyic cryometamorphized raw-humus cryozem (tundra) } \\
\hline CRcrm, 2-57 & 0.5 & 35.3 & 49.0 & 7.8 & 6.9 & 0.5 & 15.2 & 0.98 & 2.61 \\
\hline $\mathrm{CRg} \perp, 57-65$ & 0.3 & 30.6 & 49.8 & 9.4 & 5.7 & 4.2 & 19.3 & 0.94 & 2.62 \\
\hline \multicolumn{10}{|c|}{ Pit P-04.09.Al, gelyic raw-humus cryozem (larch, northern taiga) } \\
\hline $\mathrm{CRg} \perp, 12-36$ & 1.2 & 23.6 & 38.0 & 11.4 & 12.3 & 13.5 & 37.2 & 3.15 & 2.53 \\
\hline $36-50$ & 0.3 & 19.6 & 39.6 & 10.2 & 14.7 & 15.6 & 40.5 & 1.76 & 2.69 \\
\hline \multicolumn{10}{|c|}{ Central Yakutian Plain } \\
\hline \multicolumn{10}{|c|}{ Pit P-01-11*, permafrost-affected palevaya soil (larch, middle taiga) } \\
\hline $\mathrm{B}, 11(24)-25(30)$ & 7.1 & 31.2 & 22.8 & 9.0 & 11.5 & 18.4 & 38.9 & 1.34 & 2.62 \\
\hline Bca, 25(30)-56 & 5.7 & 25.2 & 27.8 & 9.4 & 13.5 & 18.4 & 41.3 & 1.15 & 2.68 \\
\hline Cca, 56-88 & 7.2 & 29.9 & 23.8 & 12.7 & 9.8 & 17.2 & 39.7 & 1.09 & 2.64 \\
\hline
\end{tabular}

HW is hygroscopic water. *Symbols of soil horizons are given according to [10].

Table 2. Some physicochemical properties of cryozems of the Anabar and Alazeya plateaus

\begin{tabular}{l|l|l|l|l|l|l|}
\hline & & & \multicolumn{3}{|c|}{$\begin{array}{c}\text { Exchangeable cations } \\
\text { (Gedroits method) }\end{array}$} \\
Horizon; depth, cm & \multirow{2}{*}{$\mathrm{pH}$ water } & $\mathrm{C}_{\text {org }}\left(\mathrm{LOI}^{*}\right), \%$ & $\begin{array}{c}\mathrm{Ac}_{\mathrm{tot}}, \\
\mathrm{cmol}(+) / \mathrm{kg}\end{array}$ & $\mathrm{Ca}^{2+}$ & $\mathrm{Mg}^{2+}$ & $\mathrm{H}^{+}$ \\
\cline { 4 - 7 } & & & \multicolumn{2}{|c|}{$\mathrm{cmol}(+) / \mathrm{kg}, \%$} \\
\hline
\end{tabular}

Anabar Plateau

\begin{tabular}{|c|c|c|c|c|c|c|c|}
\hline \multicolumn{8}{|c|}{ Pit P-18.12.A, gleyic raw-humus cryozem (tundra) } \\
\hline Oao, 7-12 & 6.8 & $59.2 *$ & 16.3 & 83.0 & 28.6 & - & 87.2 \\
\hline $\mathrm{CRg}, 12-31$ & 7.9 & 2.4 & 0.5 & 25.6 & 9.0 & - & 98.5 \\
\hline $\mathrm{Cg} \perp, 31-50$ & 7.4 & 0.9 & 1.2 & 14.9 & 7.7 & - & 94.9 \\
\hline \multicolumn{8}{|c|}{ Pit P-12.12.A, gleyic raw-humus cryozem (larch woodland) } \\
\hline Oao, 3-8 & 4.2 & $80.8^{*}$ & 67.4 & 24.7 & 11.9 & 28.3 & 35.1 \\
\hline CRg, 8-34 & 6.3 & 1.8 & 3.8 & 14.5 & 6.7 & 0.2 & 84.8 \\
\hline$C \perp, 34-60$ & 6.9 & 1.9 & 2.2 & 15.4 & 8.4 & 0.0 & 91.5 \\
\hline
\end{tabular}

Pit P-31.08.Al, gleyic cryometamorphized raw-humus cryozem (tundra)
CRcrm, 2-57
$\mathrm{CRg} \perp, 57-65$
\begin{tabular}{l|l}
5.9 & 0.7 \\
6.1 & 0.8
\end{tabular}
4.8
4.0
5.4
5.2
4.5
4.2
0.7
0.5
67.3

Pit P-04.09.Al, gleyic raw-humus cryozem (larch, northern taiga)

\begin{tabular}{c|c|c|c|c|c|c|c} 
Oao, $10-12$ & 4.8 & $43.7^{*}$ & 46.3 & 27.6 & 10.6 & 8.5 & 45.2 \\
$\mathrm{CRg} \perp, 12-36$ & 6.9 & 1.1 & 3.6 & 13.7 & 4.9 & 0.02 & 83.8 \\
$36-50$ & 7.1 & 1.2 & 2.9 & 12.6 & 3.8 & 0.01 & 85.2 \\
\hline
\end{tabular}

Here and in Table 3, LOI is the loss on ignition, $\mathrm{Ac}_{\text {tot }}$ is the total (hydrolytic) acidity, and BS is base saturation; dashes stand for "not determined." 
Table 3. Some physicochemical properties of the palevaya soil of Central Yakutia

\begin{tabular}{|c|c|c|c|c|c|c|c|c|c|}
\hline \multirow{3}{*}{$\begin{array}{l}\text { Horizon; } \\
\text { depth, cm }\end{array}$} & \multirow{3}{*}{$\mathrm{pH}$ water } & \multirow{3}{*}{$\begin{array}{c}\mathrm{C}_{\text {org }} \\
\left(\mathrm{LOI}^{*}\right), \%\end{array}$} & \multirow{3}{*}{$\mathrm{C}_{\text {carb, }} \%$} & \multirow{3}{*}{$\begin{array}{c}\mathrm{Ac}_{\text {tot }}, \\
\operatorname{cmol}(+) / \mathrm{kg}\end{array}$} & Excha & able cat & (Pfeff & thod) & \multirow{3}{*}{ BS, $\%$} \\
\hline & & & & & $\mathrm{Ca}^{2+}$ & $\mathrm{Mg}^{2+}$ & $\mathrm{Na}^{+}$ & $\mathrm{K}^{+}$ & \\
\hline & & & & & \multicolumn{4}{|c|}{$\mathrm{cmol}(+) / \mathrm{kg}$} & \\
\hline
\end{tabular}

Pit P-01-11, permafrost-affected palevaya soil (larch, middle taiga)

\begin{tabular}{l|c|c|c|c|c|c|c|c|c|c} 
O, 0-6(20) & 4.3 & $75.8^{*}$ & None & 58.8 & - & - & - & - & - \\
A, 6(20)-11(24) & 4.9 & 7.2 & None & 17.1 & 7.8 & 6.1 & 0.2 & 0.3 & 31.5 \\
B, 11(24)-25(30) & 6.7 & 0.9 & 0.15 & 1.5 & 11.5 & 6.4 & 0.2 & 0.2 & 92.4 \\
Bca, 25(30)-56 & 7.8 & 0.7 & 0.23 & - & 13.3 & 4.2 & 0.1 & 0.2 & - \\
Cca, 56-88 & 7.9 & 0.5 & 0.32 & - & 13.4 & 3.2 & 0.2 & 0.2 & - \\
\hline
\end{tabular}

chlorite, and irregular mixed-layer chlorite-vermiculite were present; among non-clay minerals, quartz and feldspars were identified. All these minerals are inherited from the parent material. As a tendency, a decrease in the share of chlorite in the upper mineral horizon (CRcrm) in soil profile P-31.08.A (tundra zone) should be noted; this can be judged from a decrease in the intensity of $14 \AA$ reflection relative to the intensity of $10 \AA$ reflection on the XRD patterns of the samples in the air-dry state (Fig. 3). As an increase in the proportion of irregular mixed-layer chloritevermiculite structures-products of chlorite transformation-has not been identified, it can be concluded that the destruction/dissolution of chlorite takes place in this soil.

Profile P-01-11 (Central Yakutia) contains irregular mixed-layer mica-smectite, illite, chlorite, and kaolinite; among non-clay minerals, quartz, feldspars, and calcite (in the lower Bca and Cca horizons) are present. The mineralogical composition of this soil differs from the soils of the Anabar Plateau, in which the association of clay minerals is the same, in a higher proportion of chlorite, especially in the lower horizons (Fig. 4). As judged from the ratio of mineral phases, there are no significant changes in the mineralogical composition between the horizons of this profile.

However, certain differences between the horizons should be noted. The intensity of the peaks (001) of minerals is very low in the clay fraction of the upper (O) horizon. This is due to the high content of X-ray amorphous substances, including soil organic matter, which manifests itself in a high background in the range of angles $20^{\circ}-30^{\circ}$ in the XRD patterns of air-dry samples. In the A and B horizons, a decrease in the proportion of chlorite in comparison with lower horizons was identified from a lower reflection intensity at $14 \AA$ compared to $10 \AA$ in the diffraction patterns of heated samples. As the mixed-layer chlorite-vermiculite (smectitic) structures have not been identified in this soil profile, the decrease in the chlorite proportion reflects the partial dissolution of the mineral rather than its transformation into mixed-layer structures.

\section{DISCUSSION}

Soils of the Anabar and Alazeya plateaus. Despite the close occurrence of permafrost, only the soils of the Anabar Plateau have a relatively high organic carbon content in the mineral horizons (especially, in the CRg horizon of pit P-18.12.A). This is in agreement with the concept of a significant humus content in the cryoturbated permafrost-affected soils [28]. In comparison with the soils of the Alazeya Plateau, the soils of the Anabar Plateau have higher values of base saturation, which is possibly due to the influence of ancient calcareous bedrock, the inclusions of which were diagnosed in one of the profiles.

On the Anabar Plateau, two profiles of gleyic rawhumus cryozems (P-18.12.A and $\mathrm{P}-12.12 . \mathrm{A})$ were studied. On their example, the potential possibility of the contribution of hard bedrock, the inclusions of which were diagnosed in large quantities in one of the profiles (P-18.12.A), to the mineralogical composition of the clay fraction can be considered. Earlier, using the example of gravelly soil on moraine deposits composed of rocks of different geneses and compositions, it was shown that minerals inherited from the bedrock less resistant to weathering are present in the clay fraction of the moraine; the fine earth of the soil is also derived from this bedrock [39]. The soils studied on the Anabar Plateau have identical mineralogical composition, which means that the inclusions of bedrock debris (gravel) are not an additional resource for mineral phases differing in their composition from those diagnosed in the fine earth.

Weakly pronounced differentiation of clay minerals in the soil profile was only identified in pit R-18.12.A studied in the tundra zone. Though the $\mathrm{pH}$ values in the mineral horizons of this profile are in the alkaline range, the content of smectitic structures in the CRg horizon of this soil is lower than that in the underlying $\mathrm{Cg}$ horizon. The high $\mathrm{pH}$ values are due to the fact that the tributaries of the Anabar River flows through the massif of Cambrian rocks represented by dolomite and, less often, limestone. Note that this soil did not 
P-18.12A

I

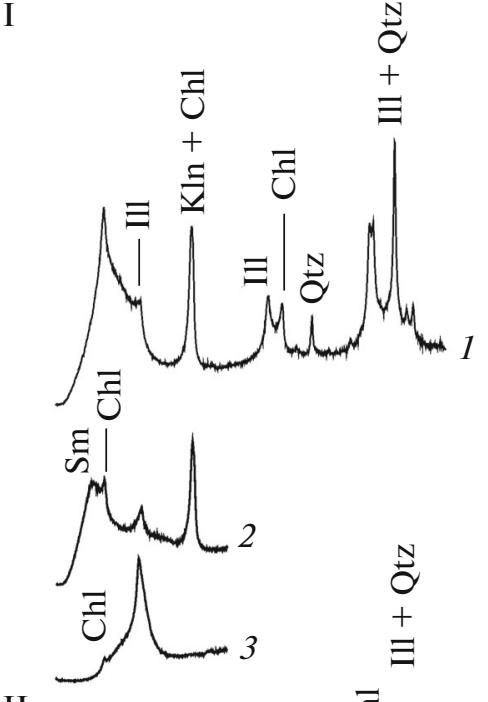

II
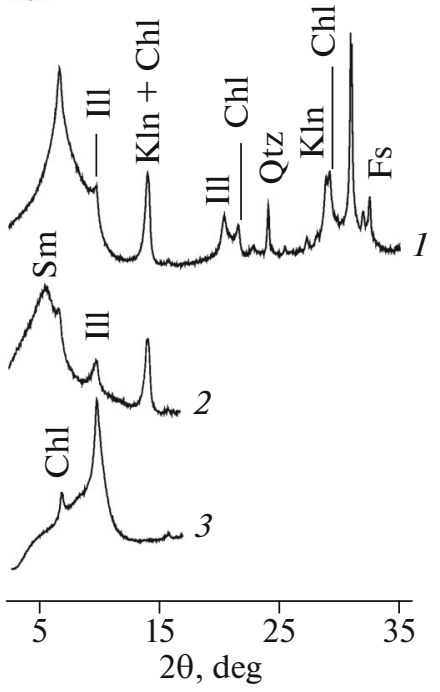

P-12.12A

I

II
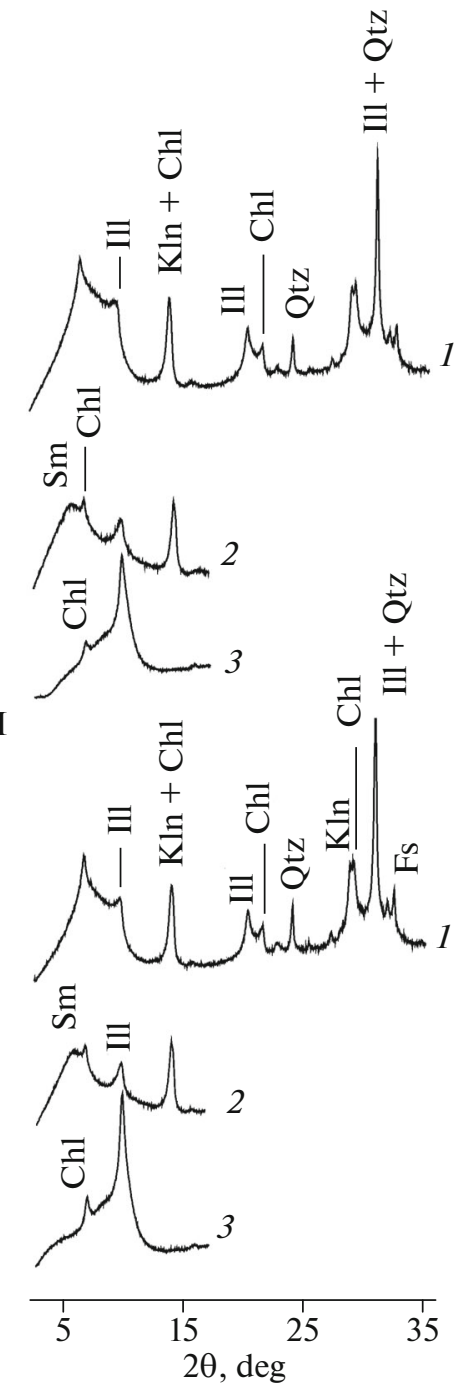

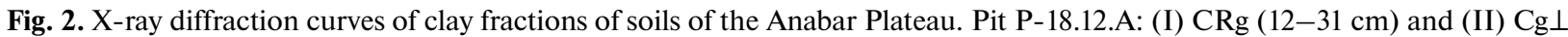
(31-50 cm); pit 12.12.A: (I) CRg $(8-34 \mathrm{~cm})$ and (II) $\mathrm{C} \perp(34-60 \mathrm{~cm})$. Here and in Figs. 3 and 4: Kln, kaolinite; Ill, illite; Chl, chlorite; Sm, smectitic structures; Chl/V, mixed-layer chlorite-smectite; Qtz, quartz; Fs, feldspars; Cal, calcite. Sample pretreatement: (1) saturation with $\mathrm{Mg},(2)$ ethylene glycol solvation, and (3) heating at $550^{\circ} \mathrm{C}$.

effervesce with $\mathrm{HCl}$. At the same time, the bulk sample from the upper mineral horizon could be more alkaline than the fragments of this horizon immediately under the litter. This assumption is supported by the fact of the highest value of total acidity in the profile in litter (Oao) horizon. According to the hypothesis about selective destruction/dissolution of minerals, smectitic structures are the least stable component of clay minerals [25]. Partial destruction of the smectitic structures may occur immediately under the litter in local most acid loci. It is probable that this process is rather active in the considered cryozems. However, its effect is leveled by active cryoturbation, so that the mineral material of the soil remains slightly differentiated.
As well as in the soils of the Anabar Plateau, weak differentiation of clay minerals along the soil profile is traced as a tendency only in the cryozem of the tundra zone (pit P-31.08.Al). The soil reaction in this profile is more acid ( $\mathrm{pH}$ 5.9-6.1), and the soil texture is coarser than that in the cryozem of the larch woodland. In this cryozem, partial destruction of chlorite takes place, as the proportion of this mineral decreases in the upper mineral horizons. The destruction of chlorite occurs without the appearance of mixed-layer structures, which is one of the possible scenarios in acid soils [37, 42].

The mineralogical composition of the studied soils of the Alazeya Plateau is similar to that of in the cryozems of yedoma landscapes of the Kolyma Low- 
P-31.08Al

I

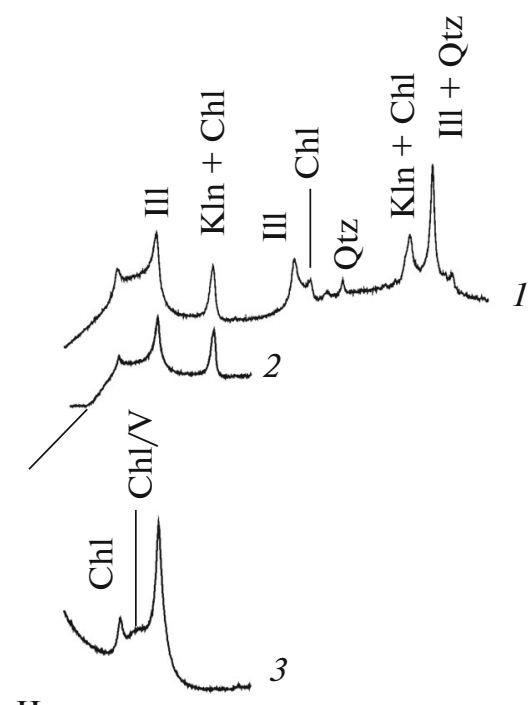

II

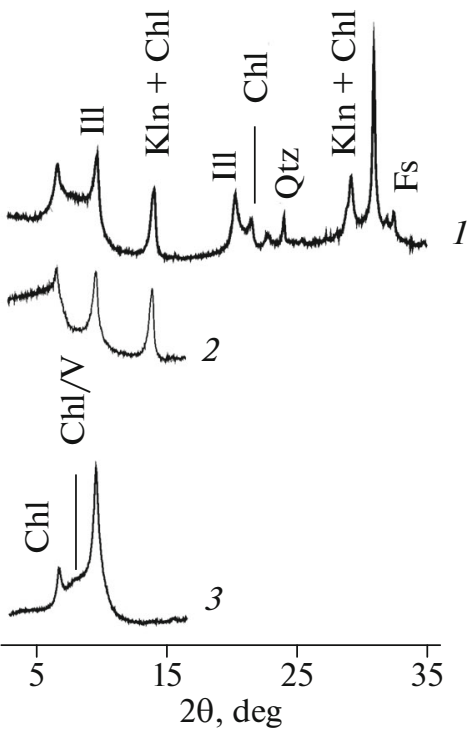

P-04.09Al

I
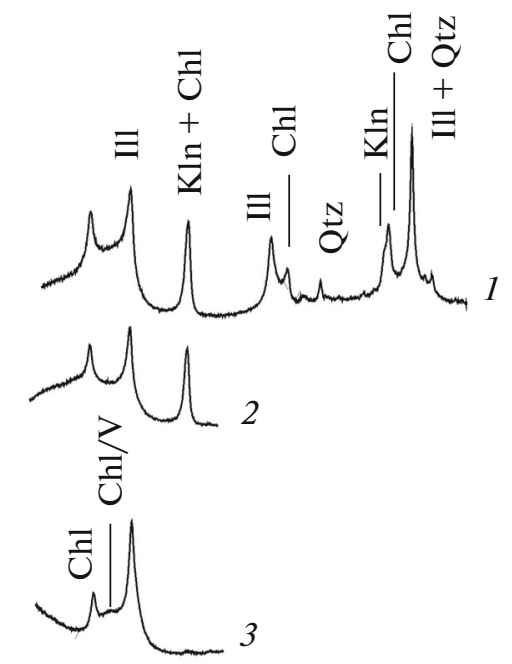

II
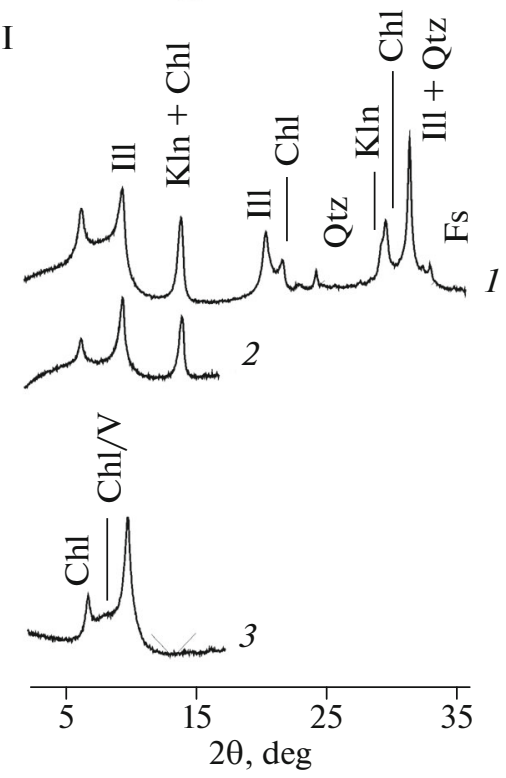

Fig. 3. X-ray diffraction curves of clay fractions of soils of the Alazeya Plateau. Pit P-31.08.Al: (I) CRcrm (2-57 cm) and (II) $\mathrm{CRg} \perp(57-65 \mathrm{~cm})$; pit P-04.09.Al: (I) $\mathrm{CRg} \perp(12-36 \mathrm{~cm})$ and (II) $\mathrm{CRg} \perp(36-50 \mathrm{~cm})$.

land located northeast of the Alazeya Plateau. In the yedoma soils, despite the slightly acid or neutral reaction, the transformation of chlorite and illite into irregular mixed-layer structures and the formation of lepidocrocite $(\gamma \mathrm{FeOOH})$ at the cryogenic barrier were noted [27]. The same mineralogical composition was described for the soils along the Kolyma River within the Kolyma Lowland. Minor changes of clay minerals in the profile were attributed to the transformation of illite into vermiculite [31]. Changes in the mineral structure along the profile of pit $\mathrm{P}-31.08$. Al are associated only with chlorite and, in contrast to the soils of the Kolyma Lowland, do not affect illite, which is more stable in an acidic environment in accordance with the hypothesis of selective destruction of minerals [25]. Thus, in the studied soils of the Alazeya Plateau, the transformation of the mineral phase is less intense than in the cryozems of the Kolyma Lowland.

In general, our data on the mineralogical composition of soils of the Anabar and Alazeya plateaus indicate a weak activity of weathering processes, which is generally typical for high latitudes [29]. In all the profiles, the redistribution of the most responsive to the action of pedogenesis clay fraction is virtually absent, which attests to a weak pedogenic potential of cold ultracontinental climatic conditions. In addition, the homogeneity of soil profiles is naturally due to the 


$$
\text { P-01-11 }
$$

I
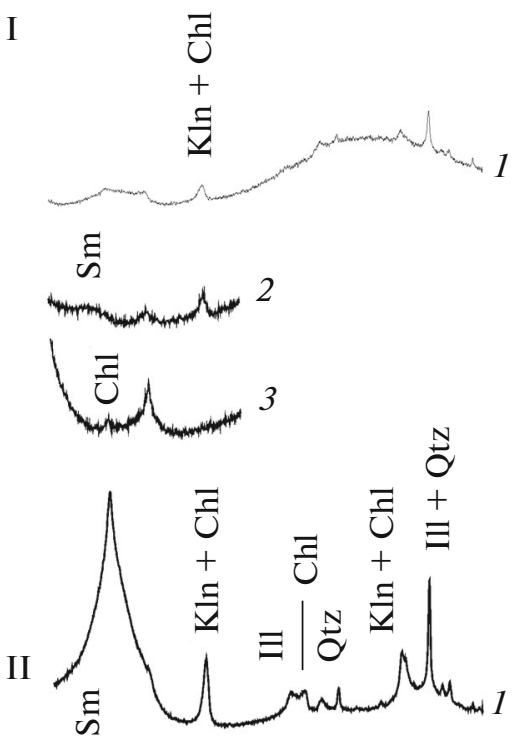<smiles>CCCCCCCCCCCCCCCCCCC</smiles>
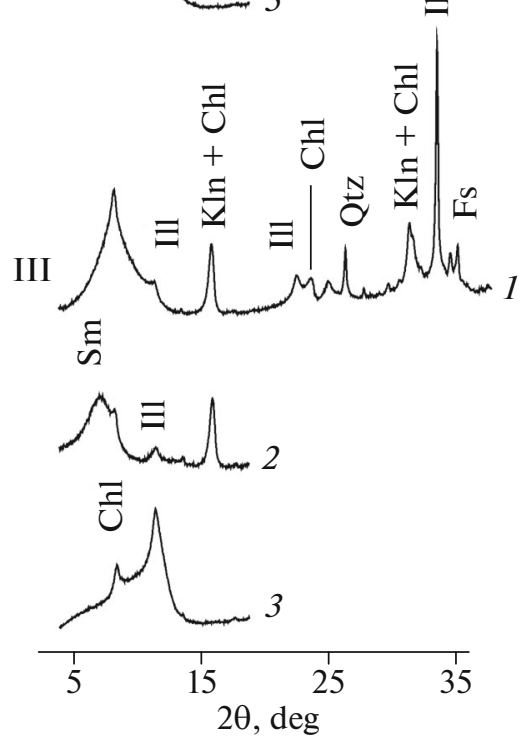

IV
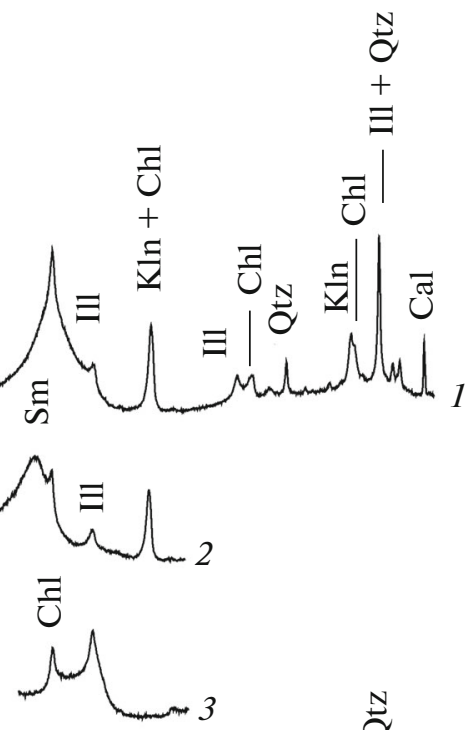

$\stackrel{N}{0}$
+
$\equiv$

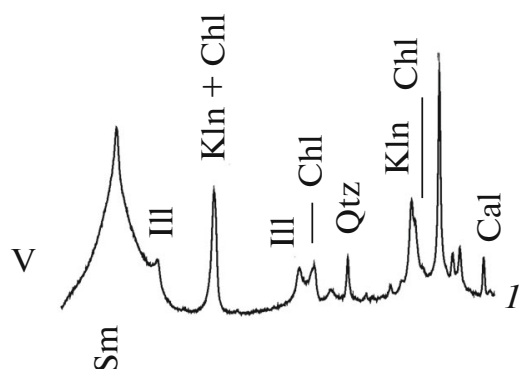

$M_{\bar{U}} \equiv L_{2}$

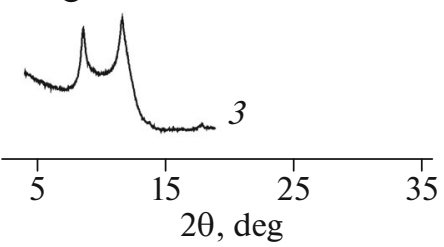

Fig. 4. X-ray diffraction curves of clay fractions from the palevaya soil of the Central Yakutian Plain (pit P-01-11): (I) O (0-6(20) cm), (II) A (6(20)-11(24) cm), (III) B (11(24)-25(30) cm), (IV) Bca $(25(30)-56 \mathrm{~cm})$, and (V) Cca $(56-88 \mathrm{~cm})$.

action of cryogenic processes (cryoturbation) mixing the soil material.

Palevaya soil of Central Yakutia. Earlier, it was proposed to introduce the type of soddy-pale soils into the Russian soil classification system [12, 20], because the soddy (gray-humus) horizon is clearly expressed in them: AY-BPL-BCA-Cca [8]. In the humus horizon of these soils, $\mathrm{pH}$ values remain in the acidic range. At the same time, sodium may be present (but not necessary) in the composition of adsorbed cations. The presence of exchangeable sodium is consistent with the hypothesis of Ivanova [11] about the possibil- 
ity of the development of modern podzolization in the soils with distinct solodic features. In this case, solodic features reflect the previous stage of soil formation.

As shown in $[2,7]$, the properties of the humus horizon in the pale soils are transitional between those of the light-humus (AJ) and gray-humus (AY) horizons. In profile R-01-11, the humus-accumulative horizon has an acid reaction and contains a small amount of exchangeable sodium. Taking into account the analysis of our data [18] and diagnostic features of the gray-humus horizon [12, 20], the humus-accumulative horizon in pit $\mathrm{P}-01-11$ should be classified as a gray-humus (AY) horizon.

In addition to this horizon, which is characteristic of soils forming in more humid environments, the distribution of clay minerals in the profile of the palevaya soil (pit P-01-11) is rather specific. Differentiation of clay minerals in the profile is due to the partial dissolution of chlorite in the upper horizon A or AY (according to $[12,20]$ ) and the B (BPL) horizon. However, only in the AY horizon, the $\mathrm{pH}$ value is in the acidic range, which explains the dissolution of chlorite. It can be assumed that, in the neutral BPL horizon, the destruction/dissolution of chlorite occurs in more acidic loci (e.g., near the roots) in comparison with the bulk soil mass of large samples. In turn, the disagreement between relatively high $\mathrm{pH}$ values in the BPL horizon and the destruction of chlorite in it can be explained by the influence of the multidirectional migration of carbonate solutions on the soil acidity. The alternation of descending migration of soil solution in wet seasons and ascending migration to the freezing front in autumn for permafrost soils in Yakutia was shown by Zol'nikov [9].

The next controversial aspect of the profile distribution of clay minerals is the fact that, despite a decrease in the proportion of chlorite in the AY and BPL horizons, the proportion of smectitic structures, which are most unstable in an acidic medium [25], does not change along the profile. It can be assumed that the inherited smectitic structures and chlorite, are dissolved in the upper horizons of the profile. In this case, a stable content of smectitic structures in these horizons can be maintained due to the transformation of illite into irregular mixed-layer mica-smectite structures. In turn, the inflow of illite is possible due to its release from coarser fractions during their disintegration. This scheme is typical for much more humid and acidic soils and was first considered for podzols of Fennoscandia [32]. In addition, it was shown that chlorite is the first to disappear from the coarse fractions [40]. This assumption is in good agreement with the data on pale soils of Central Yakutia, for which several variants of the profile distribution of clay minerals have been revealed [38]. The most complicated distribution is associated with the partial dissolution of smectitic structures inherited from the parent rock and the appearance in of pedo- genic smectitic structures-products of the transformation of illite and chlorite into mixed-layer structures-in the upper horizons. In the underlying Bca and Cca (BCA and Cca, respectively) horizons (pit P-01-11), the $\mathrm{pH}$ values are in the alkaline range, which is due to the presence of carbonates. In these horizons, no changes in the ratio of mineral phases have been noted. The presence of carbonate pedofeatures in the profile is consistent with a relatively significant wetting of the area, where annual precipitation reaches $300 \mathrm{~mm}$.

Thus, our data indicate that the weathering of the mineral phase in the studied palevaya soil is more developed despite the absence of pronounced trends in the profile differentiation of clay minerals. This conclusion is consistent with the presence of a soddy horizon in the profile, which is characteristic of acidic soils in more humid regions, and confirms our statement about the gray-humus nature of the humus horizon in the permafrost-affected pale soils of Central Yakutia. Thus, the profile described in pit $\mathrm{P}-01-11$ has the following horizonation: O (0-6(20) cm-AY (6(20)-11(24)) cmBPL (11(24)-25(30)) cm-BCA (25(30)-56) cmCca $(56-88) \mathrm{cm}$, and the soils should be classified as soddy-pale soils. The obtained results complement the ideas about the mineralogical composition of pale-colored soils in central Yakutia advanced in the 1970s [24]: it was believed that there is no clear differentiation of clay minerals along the profiles of both undifferentiated pale-calcareous soils and morphologically differentiated solodized pale soils. We argue that weathering and mineral transformation in pale soils of Central Yakutia are more pronounced than it was considered before.

\section{CONCLUSIONS}

The soils of the Anabar and Alazey plateaus are characterized by poorly pronounced morphological and chemical-mineralogical differentiation, which is due to the low activity of weathering and soil formation. In addition, the homogenization of soil profiles can be due to the influence of cryoturbation. Weakly expressed processes of the profile differentiation of clay minerals caused by the partial destruction/dissolution of the most unstable minerals in an acid medium were noted only in the soils of the tundra zone. The manifestation of these processes in the soils with neutral or slightly alkaline reaction is possibly associated with the formation of more acidic loci in the mineral horizon directly under the litter, which, however, cannot be identified by traditional methods of $\mathrm{pH}$ measurements in large samples.

In the profile of permafrost-affected palevaya soil of Central Yakutia, partial dissolution of chlorite is observed in the upper horizons with an acid and neutral reaction, while the proportion of smectitic structures that are more unstable in an acid medium does not change along the profile. It can be assumed that the inherited smectitic structures, like chlorite, dis- 
solve/disintegrate in the upper horizons of the profile, but the transformation of illite into irregular micasmectite structure provides for maintaining a stable content of smectitic structures. Accordingly, it is logical to assume that the weathering of the mineral phase in the studied permafrost-affected palevaya soil is more developed, despite the absence of pronounced trends in the profile differentiation of clay minerals. This assumption is consistent with the presence of a thick humus horizon in the profile and confirms our statement about the gray-humus nature of the humus horizon in the pale soils of Central Yakutia. We argue that these soils are characterized by the AY-BPL-BCA$\mathrm{BCca}$ horizonation and should be classified as the type of soddy palevye (soddy pale) soils within the framework of the new Russian soil classification system.

\section{ACKNOWLEDGMENTS}

XRD data were obtained at the resource center "X-Ray Diffraction Research Methods" of St. Petersburg State University.

\section{FUNDING}

This study was supported by the Russian Foundation for Basic Research (project nos. 20-04-00888 and 19-29-05151); field works were performed in agreement with the state assignment of the Institute of Biological Problems of the Cryolithozone, project V.54.1.2 (0376-2018-0003), state registration number AAAA-A17-117020110057-7.

\section{CONFLICT OF INTEREST}

The authors declare that they have no conflicts of interest.

\section{OPEN ACCESS}

This article is licensed under a Creative Commons Attribution 4.0 International License, which permits use, sharing, adaptation, distribution and reproduction in any medium or format, as long as you give appropriate credit to the original author(s) and the source, provide a link to the Creative Commons license, and indicate if changes were made. The images or other third party material in this article are included in the article's Creative Commons license, unless indicated otherwise in a credit line to the material. If material is not included in the article's Creative Commons license and your intended use is not permitted by statutory regulation or exceeds the permitted use, you will need to obtain permission directly from the copyright holder. To view a copy of this license, visit http://creativecommons.org/licenses/by/4.0/.

\section{REFERENCES}

1. R. I. Abolin, Geobotanical and Soil Description of the Lena-Vilyui Plain, Tr. Kom. Izuch. Yakut. ASSR, vol. 10 (Academy of Sciences of the USSR, Leningrad, 1929) [in Russian].
2. T. V. Ananko, M. I. Gerasimova, and D. E. Konyushkov, "Pale soils on noncalcareous rocks of Central Siberia in the soil classification system of Russia," Byull. Pochv. Inst. im. V.V. Dokuchaeva, No. 77, 29-50 (2015).

3. A. A. Velichko, Environmental Processes in the Pleistocene (Nauka, Moscow, 1973) [in Russian].

4. I. P. Gerasimov, "On the specificity of genetic types of Siberian soils," in Siberian Geographical Collection of Scientific Papers (Academy of Sciences of the USSR, Moscow, 1963), pp. 10-25.

5. B. B. Gerasimov, R. Yu. Zhelonkin, and A. L. Zemnukhov, "Typomorphism of fine placer gold and potential primary sources of the Anabar mineral subprovince (the northeast of the Siberian Platform), " Prir. Resur. Arkt. Subarkt. 24 (4), 37-48 (2018). https://doi.org/10.31242/2618-9712-2019-24-4-3

6. S. V. Goryachkin, Soil Cover of the North: Structure, Genesis, Ecology, and Evolution (GEOS, Moscow, 2010) [in Russian].

7. E. A. Gurkova, M. A. Bronnikova, M. I. Gerasimova, E. Yu. Sukhacheva, and Yu. V. Konoplyanikova, "Light-humus carbonate-accumulative and pale-metamorphic soils from the collection of the Central Museum of Soil Science: verification of typical diagnostics," Byull. Pochv. Inst. im. V.V. Dokuchaeva, No. 98, 37-56 (2019).

https://doi.org/10.19047/0136-1694-2019-98-37-56

8. R. V. Desyatkin, S. N. Lesovaya, M. V. Okoneshnikova, and T. S. Zaitseva, "Palevye (pale) soils of Central Yakutia: Genetic specificity, properties, and classification,” Eurasian Soil Sci. 44, 1304-1314 (2011).

9. V. G. Zol'nikov, "Soils of the eastern half of Central Yakutia and their uses," in Materials on the Environmental Conditions and Agriculture of Central Yakutia (Academy of Sciences of the Soviet Union, Moscow, 1954), No. 4, pp. 55-222.

10. L. G. Elovskaya, Classification and Diagnostic System of Permafrost-Affected Soils of Yakutia (Yakut Branch, Academy of Sciences of Soviet Union, Yakutsk, 1987) [in Russian].

11. E. N. Ivanova, "Soils of Central Yakutia," Pochvovedenie, No. 9, 3-17 (1971).

12. L. L. Shishov, V. D. Tonkonogov, I. I. Lebedeva, and M. I. Gerasimova, Classification and Diagnostic System of Russian Soils (Oikumena, Smolensk, 2004) [in Russian].

13. Permafrost Systems of the Alazeya River Basin, Ed. by A. P. Isaev and I. V. Klimovskii (GEO, Novosibirsk, 2018) [in Russian]. ISNB 978-5-9909584-0-1

14. Permafrost-Landscape Map of Yakut ASSR, Scale 1 : 2500000 , Ed. by P. I. Mel'nikov (General Office of Geodesy and Cartography, Moscow, 1991) [in Russian].

15. Permafrost Landscapes of Yakutia (Explanatory Note to Permafrost-Landscape Map of Yakut ASSR, Scale 1: 2500000), Ed. by A. N. Fedorov, et al. (General Office of Geodesy and Cartography, Novosibirsk, 1989) [in Russian].

16. V. E. Minorin, V. M. Podchasov, I. Ya. Bogatykh, S. A. Grakhanov, and V. I. Shatalov, Geology, Forecasting, Methods of Search and Exploration of Diamond De- 
posits. Placer Deposits (Yakut Branch, Russian Academy of Sciences, Yakutsk, 2004) [in Russian].

17. Handbook on Climate of the Soviet Union, Vol. 24: Yakutia ASSR (Gidrometeoizdat, Leningrad, 1989), Book 1.

18. M. V. Okoneshnikova, S. N. Lessovaia, and R. V. Desyatkin, "Soils of larch forests of the Spasskaya Pad and Elgyay experimental forest stations (Central Yakutia)," Prir. Resur. Arkt. Subarkt. 25 (3), 71-79 (2018). https://doi.org/10.31242/2618-9712-2018-25-3-71-79

19. Yu. P. Parmuzin, Nature of Central Siberia (Mysl', Moscow, 1964) [in Russian].

20. Field Guide for Identification of Russian Soils (Dokuchaev Soil Science Inst., Moscow, 2008) [in Russian].

21. E. I. Ravskii, Sedimentation and climate of Inner Asia in Anthropogen (Nauka, Moscow, 1972) [in Russian].

22. I. A. Sokolov, "Theoretical study soils in Eastern Siberia and the Far East," Pochvovedenie, No. 5, 131-145 (1991).

23. I. A. Sokolov, T. V. Tursina, and N. I. Belousova, "Modern podzolization in the plains of Central Yakutia," Pochvovedenie, No. 12, 22-29 (1969).

24. I. A. Sokolov, E. M. Naumov, B. P. Gradusov, T. V. Tursina, and I. G. Tsyurupa, "Ultracontinental taiga pedogenesis on carbonate loamy soils in Central Yakutia," Pochvovedenie, No. 4, 11-27 (1976).

25. V. D. Tonkonogov, B. P. Gradusov, N. E. Rubilina, V. O. Targulian, and N. P. Chizhikova, "Differentiation of the mineralogical and chemical compositions of soddy-podzolic and podzolic soils," Pochvovedenie, No. 3, 68-81 (1987).

26. Yakutia (Nauka, Moscow, 1965) [in Russian].

27. A. Alekseev, T. Alekseeva, V. Ostroumov, C. Siegert, and B. Gradusov, "Mineral transformation in permafrost-affected soils, North Kolyma Lowland, Russia," Soil Sci. Soc. Am. J. 67, 596-605 (2003).

https://doi.org/10.2136/sssaj2003.0596

28. J. G. Bockheim and C. Tarnocai, "Recognition of cryoturbation for classifying permafrost-affected soils," Geoderma. 81, 281-293 (1998).

https://doi.org/10.1016/S0016-7061(97)00115-8

29. P. W. Borden, C.-L. Ping, P. J. McCarthy, and S. Naidu, "Clay mineralogy in arctic tundra gelisols, northern Alaska," Soil Sci. Soc. Am. J. 74 (2), 580-592 (2010). https://doi.org/10.2136/sssaj2009.0187

30. G. J. Churchman, "Clay minerals formed from micas and chlorites in some New Zealand soils," Clay Miner. 15 (3), 59-76 (1980). https://doi.org/10.1180/claymin.1980.015.1.05

31. N. Gentsch, R. Mikutta, O. Shibistova, B. Wild, J. Schnecker, A. Richter, T. Urich, A. Gittel, H. Šantrůčková, J. Bárta, N. Lashchinskiy, C. W. Mueller, R. Fuß, and G. Guggenberger, "Properties and bioavailability of particulate and mineral-associated organic matter in Arctic permafrost soils, Lower Kolyma Region, Russia,” Eur. J. Soil Sci. 66, 722-734 (2015). https://doi.org/10.1111/ejss.12269

32. O. Gjems, "Some notes on clay minerals in Podzol profiles in Fennoscandia," Clay Miner. 4 (24), 208-211
(1960).

https://doi.org/10.1180/claymin.1960.004.24.06

33. W. Harris and N. G. White, "X-ray diffraction techniques for soil mineral identification," in Methods of Soil Analysis, Part 5: Mineralogical Methods, SSSA Book Series, no. 5 (Soil Science Society of America, Madison, WI, 2008), pp. 81-115.

34. U. Herzschuh, L. A. Pestryakova, L. A. Savelieva, L. Heinecke, T. Böhmer, B. K. Biskaborn, A. Andreev, A. Ramisch, A. L.C. Shinneman, and H. J. B. Birks, "Siberian larch forests and the ion content of thaw lakes form a geochemically functional entity," Nat. Commun. 4, 2408 (2013).

https://doi.org/10.1038/ncomms3408

35. IUSS Working Group WRB, World Reference Base for Soil Resources 2014, Update 2015, International Soil Classification System for Naming Soils and Creating Legends for Soil Maps, World Soil Resources Reports No. 106 (UN Food and Agriculture Organization, Rome, 2015).

36. Cryosols: Permafrost-Affected Soils, Ed. by J. M. Kimble (Springer-Verlag, Berlin, 2004). https://doi.org/10.1007/978-3-662-06429-0

37. H. Kodama and J. E. Brydon, "A study of clay minerals in podzol soils in New Brunswick, eastern Canada," Clay Miner. 7, 295-310 (1968).

https://doi.org/10.1180/claymin.1968.007.3.04

38. S. N. Lessovaia, S. V. Goryachkin, R. V. Desyatkin, and M. V. Okoneshnikova, "Pedoweathering and mineralogical change in cryosols in an ultracontinental climate (Central Yakutia, Russia)," Acta Geodyn. Geomater. 10 (4), 465-473 (2013). https://doi.org/10.13168/AGG.2013.0047

39. S. N. Lessovaia, S. Goryachkin, Y. Polekhovsky, V. Ershova, and A. Filimonov, "Abiotic and biotic processes of mineral weathering in tundra soils on ultramafic and mafic rocks of the Polar Urals, Russia," in BiogenicAbiogenic Interactions in Natural and Anthropogenic Systems (Springer-Verlag, Cham, 2016), pp. 223-236. https://doi.org/10.1007/978-3-319-24987-2_18

40. K. Pederstad and P. Jørgensen, "Weathering in a marine clay during postglacial time," Clay Miner. 20, 477-491 (1985). https://doi.org/10.1180/claymin.1985.020.4.04

41. T. J. Péwé and A. Journaux, Origin and Character of Loess-Like Silt in Unglaciated South-Central Yakutia, Siberia, USSR, USGS Prof. Pap. vol. 1262 (US Geological Survey, Reston, VA, 1983), Vol. 1262.

42. G. J. Ross, C. Wang, A. I. Ozkan, and H. W. Rees, "Weathering of chlorite and mica in New Brunswick podzol developed on till derived from chlorite-mica schist," Geoderma 27, 255-267 (1982). https://doi.org/10.1016/0016-7061(82)90034-9

43. A. Sugimoto, N. Yanagisawa, D. Naito, N. Fujita, and T. C. Maximov, "Importance of permafrost as a source of water for plants in East Siberian taiga," Ecol. Res. 17 (4), 493-503 (2002). https://doi.org/10.1046/j.1440-1703.2002.00506.x

Translated by D. Konyushkov 